\title{
A literature review on industrially accepted MPPT techniques for solar PV system
}

\author{
Indresh Yadav, Sanjay Kumar Maurya, Gaurav Kumar Gupta \\ Department of Electrical Engineering, GLA University, India
}

\begin{tabular}{|c|c|}
\hline Article Info & ABSTRACT \\
\hline Article history: & \multirow{9}{*}{$\begin{array}{l}\text { Solar energy is a clean renewable energy and it is available around } 89,000 \mathrm{TW} \text { on the } \\
\text { earth surface. To get maximum power from a solar PV system with minimum power } \\
\text { transfer loss is one of the main design objectives of an energy transferring network. } \\
\text { Power electronic devices perform a very important character for an efficient PV power } \\
\text { tracking system control and either incorporates to transfer the generated power to the } \\
\text { ac/dc grid or battery storage system. In this case the duty of the power electronics } \\
\text { devices used in PV system is to track maximum power point under different operating } \\
\text { conditions of environment, so that power tracking efficiency of solar PV system can } \\
\text { be improved. This paper encapsulates based the on performance comparisions on the } \\
\text { behavior of MPP under uniform and nonuniform operating conditions and selects the } \\
\text { optimum duty cycle for industrially accepted MPPT techniques with their algorithm. }\end{array}$} \\
\hline Received Nov 13, 2018 & \\
\hline Revised Oct 18, 2019 & \\
\hline Accepted Oct 30, 2019 & \\
\hline Keywords: & \\
\hline AC/DC grid & \\
\hline MPPT techniques & \\
\hline $\mathrm{V}$ array & \\
\hline & \\
\hline
\end{tabular}

Corresponding Author:

Indresh Yadav,

Department of Electrical Engineering,

IET, GLA University,

Mathura U.P. India.

Email:indresh.yadav@gla.ac.in

\section{INTRODUCTION}

Solar PV (SPV) energy is one of the rapidly growing and most encouraging renewable energy sources in the world. In last three years, solar capacity has been increased by $370 \%$ from around $2.6 \mathrm{GW}$ to more than $12.2 \mathrm{GW}$ in India [1] alone. Solar energy is the most favourable energy resource out of all available renewable energy sources worldwide. This energy comes from endless sun energy. It has gain popularity worldwide in comparison with other renewable energy resources because it can be directly converted into electrical energy. The conversion of solar energy into electrical energy involves photovoltaic material. Earlier solar PV was very costly, but because of mass-scale production and improvement in technology, now it has become affordable to most of the consumer. These days the average cost of solar PV installation in India is around Rs.33, 000/-per $\mathrm{kW}$ (large scale). To address the issues of the cost of finance and cost of technology, 60 countries have signed the International Solar Alliance (ISA) agreement on 11 March 2018 in New Delhi. This alliance facilitates mutual cooperation for solar energy uses among more than 121 countries [2]. The solar photovoltaic cells have poor conversion efficiency. Moreover, the efficiency degraded further with an increase in temperature because of the negative temperature coefficient of the PV cell. The output of PV systems also affected by solar radiation intensity [3,4]. Light trapping, antireflection techniques and front surface optical enhancement of solar PV generation improve the output of the system [5]. These days the highest commercially available SPV conversion efficiency is $25.73 \%$ [6]. These cells are designed with hetero-junction intrinsic thin layer with pillar structure. 
Solar PV's output Voltage and current are functions of the solar irradiance and the operating temperature of the panel. Enviornmental conditions and solar irradiance changes abruptly with time which consequently changes the PV output voltage and current.The mathematical equation relating the solar irradiance, operating temperature with output PV voltage and current are given in [7,8]. The change in PV output voltage and current cause the change in maximum power point of the system. A solar PV panel of short circuit current of 8.21A and open circuit voltage of $32.9 \mathrm{~V}$ is simulated and the result is shown in Figure 1. It is evident that with the variation in the PV pannel temperature and solar irradiance the MPP shifts from its previous determined point. For extracting maximum power from a solar PV module, the designed control technique is such that it ensures the operating point characteristic(voltage-current) at maximum possible output power [9,10]; such a control technique is known as maximum powerpoint tracking (MPPT).

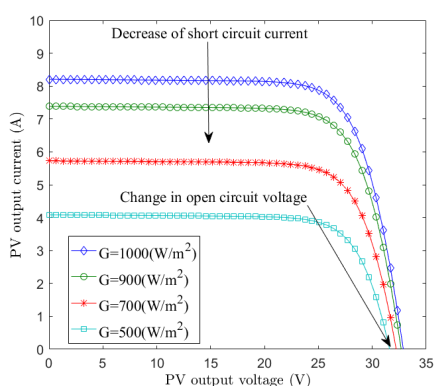

(a)

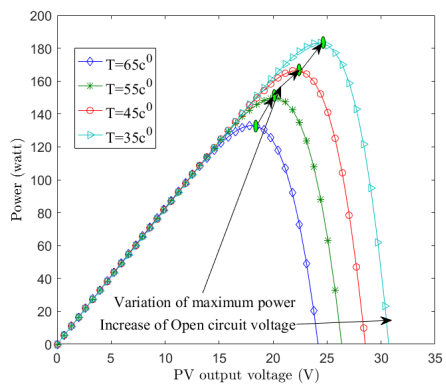

(d)

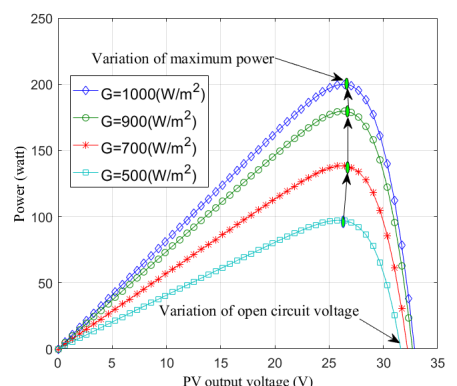

(b)

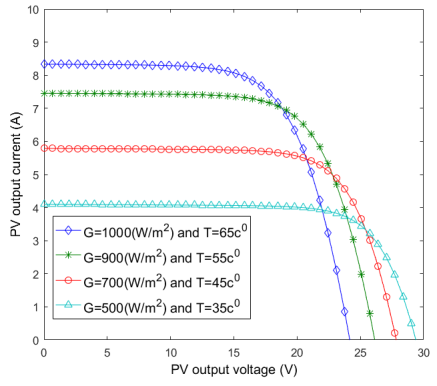

(e)

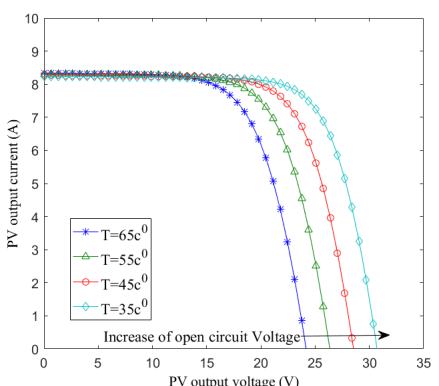

(c)

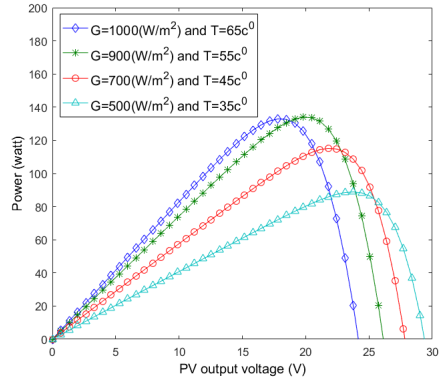

(f)

Figure 1. Solar PV characteristics for the different variation of solar Irradiance and panel temperature;(a) Current response at $25^{\circ} \mathrm{c}$ and different Irradiance,(b) Power response at $25^{\circ} \mathrm{c}$ and different Irradiance, (c)

Current response at $1000 \frac{\mathrm{W}}{\mathrm{m}^{2}}$ and different temperature, (d) Power response at $1000 \frac{\mathrm{W}}{\mathrm{m}^{2}}$ and different temperature, (e) Current Response with different temperature and Irradiancde, (f) Power Response with different temperature and Irradiancde

\section{METHODOLOGY TO ACHIEVE THE MAXIMUM POWER POINT}

The use of MPPT is to make sure that the PV operating voltage and current always stay at the MPP on PV curve. In present situation the PV pannel goes through varying enviornmental condition as shown in Figure 2(a), it shows that MP is continuously changing with different variation of solar intensity $(G)$ and panel temperature $(\mathrm{T})$; for example at $\mathrm{G}=1000 \frac{\mathrm{W}}{\mathrm{m}^{2}}$ and $\mathrm{T}=65^{\circ} \mathrm{c}$, MPP occurs at $17.5 \mathrm{~V}$ of PV voltage while at $\mathrm{G}=900 \frac{\mathrm{W}}{\mathrm{m}^{2}}$ and $\mathrm{T}=55^{\circ} \mathrm{c}$, MPP occurs at $20 \mathrm{~V}$ of PV voltage and so on. So there is a requirement of $\mathrm{dc} / \mathrm{dc}$ converter which can convert one level of PV voltage to other so that MPP can be obtained. The controlling action of dc/dc converter is done by MPPT controller. The investigation of the MPP is then carried out by changing the duty cycle of power-converters. After sensing PV output voltage and current, the MPPT algorithm generates the voltage reference signal to be controlled by the converter. The Gating signal of the converter is an important factor to get MPP. If proper gating is not done, output power will oscillate below MPP level as shown in Figure 2(b). 


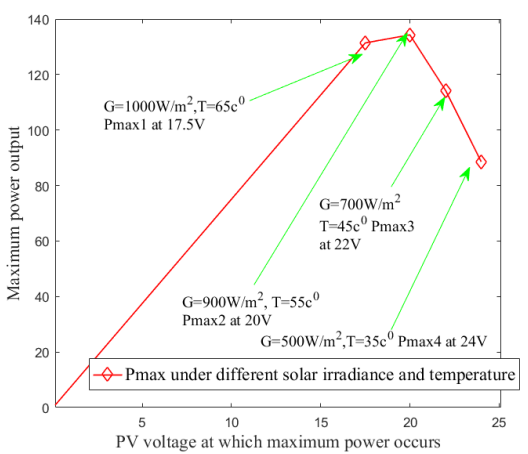

(a)

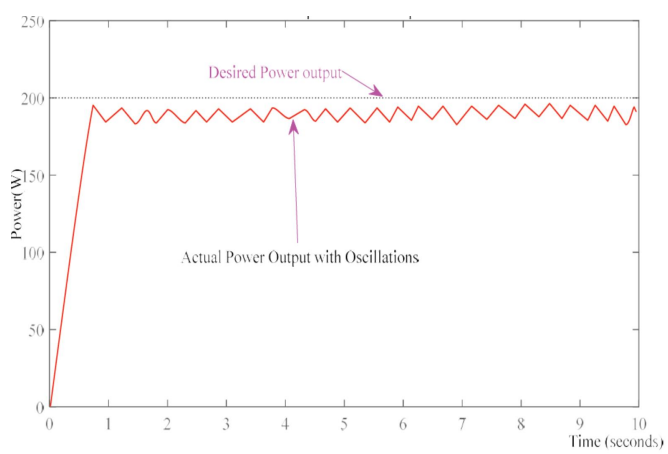

(b)

Figure 2. (a) Variation of MPP with different solar irradiance and temperature, (b) Oscillations near MPP

The interconnected block diagram of a general MPPT solar PV system is shown in Figure 3(a), [11]. This system consists of PV array, dc/dc power converter, current and voltage sensor, MPPT controller and load. PV array is made of semiconductor material which works on the principle of optical absorption; it means that PV array directly converts solar radiation energy into electrical energy followed by excess generation of electron-hole carriers. Till date a large number of researches are innovated on the design of materials and its manufacturing for PV devices so that its overall cost and efficiency can be improved. The multi-junction solar cell (InGaP/GaAs/InGaNAs) is reported to give efficiency of $44 \%$ and Thermodynamic suggests that efficiency of SPV can be raised up to $70 \%$ [12].

Dc/dc converters interface the SPV system with the variety of loads requirements and work as a MPP trackers. These converters may be buck, boost or buck boost type [13]. The input and output voltage relations of $\mathrm{dc} / \mathrm{dc}$ converter are given as follows: If $D=\frac{T_{O n}}{T}$ is the duty cycle of $\mathrm{dc} / \mathrm{dc}$ converter which lies between zero and one, then; For buck converter

$$
\frac{V_{o}}{V_{P V}}=D
$$

For boost converter

$$
\frac{V_{o}}{V_{P V}}=\frac{1}{1-D}
$$

For buck-boost converter

$$
\frac{V_{o}}{V_{P V}}=\frac{-D}{1-D}
$$

Where $V_{o}, V_{P V}, T_{o n}$ and $T_{o n}$ are output voltage, input voltage, on time and switching time period to the dc/dc converter respectively.

MPPT controller is the collection of solar PV, dc link and grid sensors (which is not mentioned in basic diagram), MPPT algorithm, and gate driver signal generation system for different converters to control the output power[14, 15]. It senses the PV output voltage and current and generates a signal which is used to control the action of dc/dc converter so that maximum power with minimum loss[16], can be obtained from the output of dc/dc converter [17]. MPP with variation of PV output voltage is in Figure 3 (b). Different MPPT algorithms which are part of MPPT controller block; to track solar the PV power with their features are discussed in this paper. 


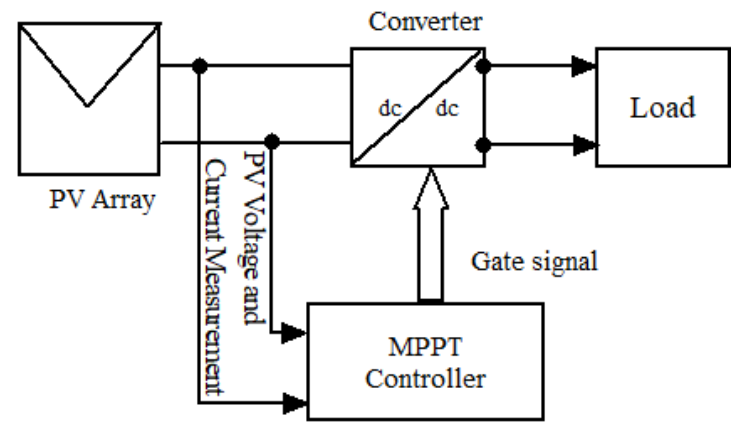

(a)

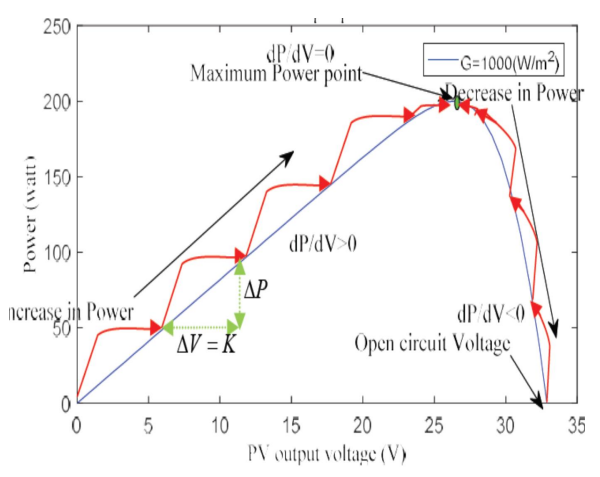

(b)

Figure 3. (a) Basic block diagram, (b) Power tracking curve of MPPT solar PV system

\section{MPPT ALGORITHM FOR DECIDING OPTIMAL DUTY CYCLE}

A notable quantity of research has already been carried out to boost the efficiency of PV tracking systems. It is important to select the best suitable MPPT based on different features for example preciseness in estimating the actual MPP, cost, speed of convergence and sensitiveness[18]. Different MPPT techniques along with their algorithm based flow-chart are given below.

\subsection{Conventional perturb and observe ( $P \& O)$}

In commercial product applications $\mathrm{P} \& \mathrm{O}$ is mostly used because it can be simply implanted, robustness, exhibits superior convergence and also requires less number of sensors [19]. This technique is applied by changing duty cycle at well organized intervals and by measuring PV current and voltage, thereby obtaining power. Once the power is known, an examination for the slope of the PV curve is carried out [20]. At the left of MPP slope is positive and at right of MPP slope is negative. In this method the maximum power tracking is done by changing the reference set voltage and then observing the system response to get the direction of the next change in system voltage [21] as shown in flow chart Figure 4 (a).

The change in reference voltage is carried-out in the direction of increment of power. This action is repeated until maximum power is reached. The algorithm of above system is described with the help of following mathematical expressions: At the left of MPP:

$$
\frac{d P_{P V}}{d V_{P V}}>0
$$

$$
V_{P V}=V_{P V}+K \text { (by increment of duty cycle) }
$$

At right of MPP:

$$
\begin{gathered}
\frac{d P_{P V}}{d V_{P V}}<0 \\
V_{P V}=V_{P V}-K \text { (by decrement of duty cycle) }
\end{gathered}
$$

At MPP:

$$
\begin{gathered}
\frac{d P_{P V}}{d V_{P V}}=0 \\
V_{P V}=V_{P V}(\text { no change of duty cycle) }
\end{gathered}
$$

Where K Shows a voltage step size (K), for the implementation of conventional P\&O algorithm [21]. Although having too many qualities, this algorithm faces two major issues. One issue is that it has continuous oscillation around its MPP and its amplitude depends on magnitude of perturbation step voltage. Other, the $\mathrm{P} \& \mathrm{O}$ fails under rapid changing solar irradiance and other environmental ambience. Both these issue contribute to the waste of power and hence shrink of the power tracking efficiency of solar PV. To overcome this issue a modified $\mathrm{P} \& \mathrm{O}$ is designed in [22], in which, the perturbation step voltage size $\mathrm{K}$ is reduced as the operating PV output voltage reaches near its MPP [23, 24]. 


\subsection{Modified adaptive perturb \& observe}

The failure of chasing direction is explained as follows. While the tracking is done on continuous basis, the change in amount of standardized power $\frac{\Delta P(k)}{P_{P V}(k)}$ is measured and correlated with a set value $\Delta M_{P r}$, where $\Delta M_{P r}$ is normalize change in PV output power and $\Delta P(k)$ is the change in power between current and previous iteration. If $\frac{\Delta P(k)}{P_{P V}(k)}<\Delta M_{P r}$, then it can be ultimate that the change in power is not adequately large, which informs that there is slow variation in solar irradiance. For this case, the step size $\mathrm{K}$ is kept low value $[22,25,26]$.

If $\frac{\Delta P(k)}{P_{P V}(k)}>\Delta M_{P r}, \mathrm{~K}$ is raised to satisfy that driving point can manage with the variation of solar irradiance. A set value of change in power with the variation of solar irradiance is given in detail in [22, 25]. At the time of continuous variation of solar irradiance incident on the panel, there will be local MPP as well as global MPP, so algorithm will set a track direction flag (TDF) to find the global MPP. If TDF=1, the algorithm will try to find the left side of the PV curve and if TDF=-1, it will try to find the right side of PV curve. Based on above two TDF based action, the algorithm will determine the gradient of $\frac{\Delta P(k)}{P_{P V}(k)}$.If the gradient is positive, which confirms absence of any local MPP and if gradient is negative, it confirms that there is local MPP (LMPP) nearby. So the algorithm will call to reach new higher value of LMPP and compares power from the previous LMPP. This process continues until global MPP (GMPP) is obtained. A boundary for PV voltage is also decided in [22]. A detail flow chart of MP\&O for rapid changing PV panel parameter is shown in Figure 4 (b).

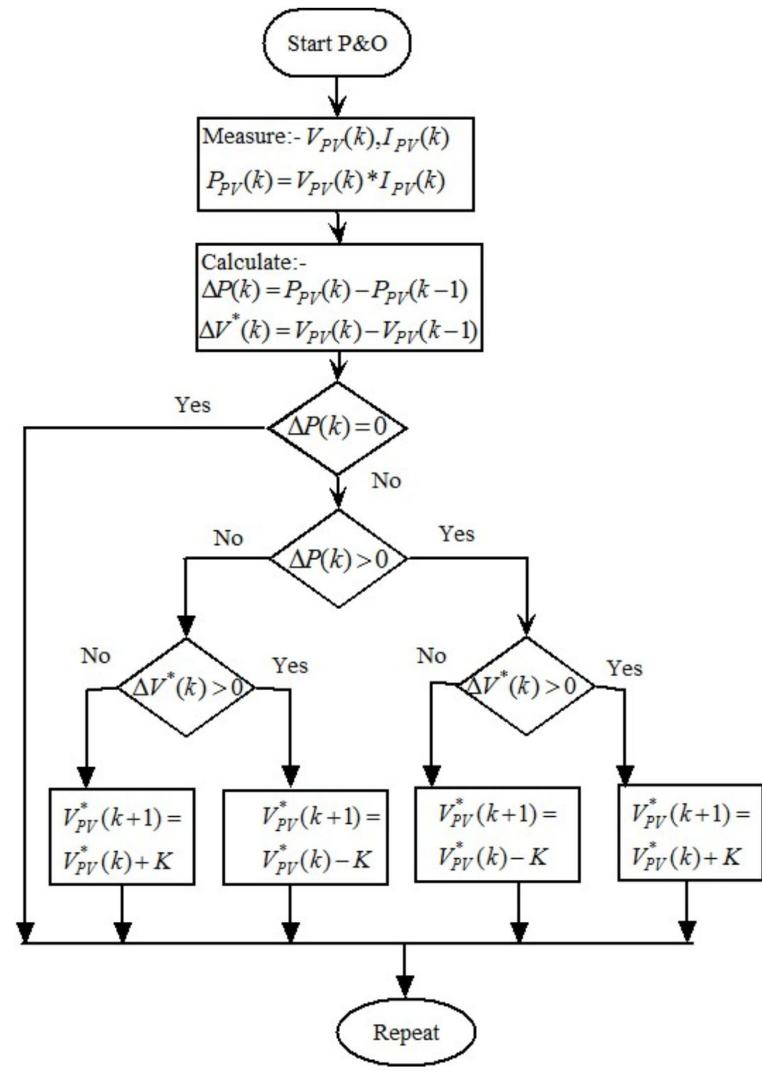

(a)

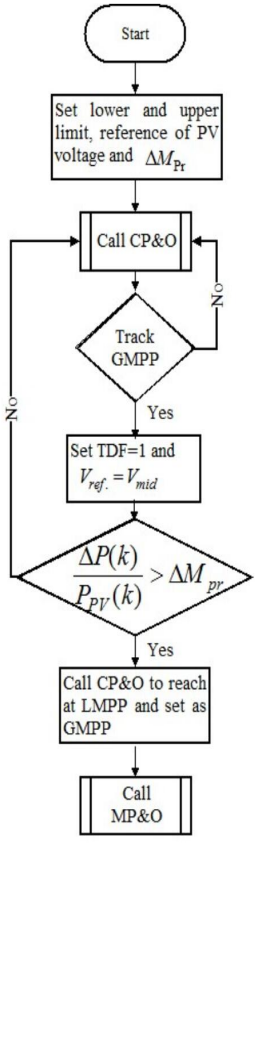

(b)

Figure 4. Flow chart; (a) Conventional P\&O algorithm, (b) Modified P\&O algorithm

\subsection{Incremental conductance}

Solar PV power tracking efficiency and speed of IC (incremental conductance) is better than the P\&O [27].This technique is acquired from the PV characteristics of solar panel. The slope of the PV characteristics can be obtained from following equations. 


$$
\frac{d p_{p v}}{d v_{p v}}=i_{P V}+v_{P V} \frac{d i_{p v}}{d v_{p v}}
$$

At the left of MPP:

$$
\frac{d p_{p v}}{d v_{p v}}>-\frac{I_{P V}}{V_{P V}}
$$

$$
V_{P V}=V_{P V}+K \text { (by increment of duty cycle) }
$$

At right of MPP:

$$
\begin{gathered}
\frac{d p_{p v}}{d v_{p v}}<-\frac{I_{P V}}{V_{P V}} \\
V_{P V}=V_{P V}-K \text { (by decrement of duty cycle) }
\end{gathered}
$$

At MPP:

$$
\begin{gathered}
\frac{d p_{p v}}{d v_{p v}}=0 \\
V_{P V}=V_{P V}(\text { no change of duty cycle })
\end{gathered}
$$

The maximum power can be obtained when $\frac{d p_{p v}}{d v_{p v}}=0$, which gives $\frac{d i_{p v}}{d v_{p v}}=-\frac{I_{P V}}{V_{P V}}$ where $\frac{I_{P V}}{V_{P V}}$ and $\frac{d i_{p v}}{d v_{p v}}$ are known as conductance and incremental conductance respectively. Flow chart used in Figure 5(a), shows conventional IC algorithm.

The P\&O, used in MPPT tracking is an arithmetic division free algorithm. On the other side, IC is having more complexity in structure than P\&O [28]. However, P\&O can easily lead to inaccurate determination and also produces oscillation around MPP. On the other hand IC gives better performance than P\&O both during dynamic as well as static environment. Therefore, IC is good choice mainly during sudden variation of climate conditions [29-34]. A mathematical as well as practical comparison between IC and P\&O is also given in detail in [28,33] and experimental result at different operating frequency is compared between IC and P\&O [28]. Hardware based successful implementation of Cuk converter using IC with fixed step size is presented in details in [34]. The conventional IC (CIC) algorithm based MPPT normally employs a fixed change in step size. Thus, the corresponding design is a compromise between the dynamics and steady state oscillations. To resolve this issue, a modified with variable step size IC based MPPT [35-40] is successfully implemented both with simulation [39] and hardware [35-38]. When there is rapid change of environmental conditions, there are global maxima along with local maxima. CIC with variable step size is not able to differentiate between local and global maxima, so further modification is made to track global maxima [41-50].

\subsection{Modified incremental conductance}

At the time of uniform variation of solar radiation incident on PV panel, Controlling based on voltage control provides better accomplishment than the controlling based on current control as the voltage at $V_{M P P}$ is around 0.8 times [41, 42] of Open circuit Voltage. But at the time of non-uniform of solar radiation incident on the PV panel, GMPP is available at anywhere between zero to open circuit voltage. A flow chart based on modified incremental conductance (MIC) to track GMPP is given in Figure 5(b), and the detail information to call CIC subroutine and load variation subroutine is given in [41]. To get faster response and track GMPPT a hybrid, which is combination of IC and soft computing is employed in [47-49]. When there is GMPP as well LMMP, IC is used to track any LMPP and then soft computing is used to track GMPP [48]. 


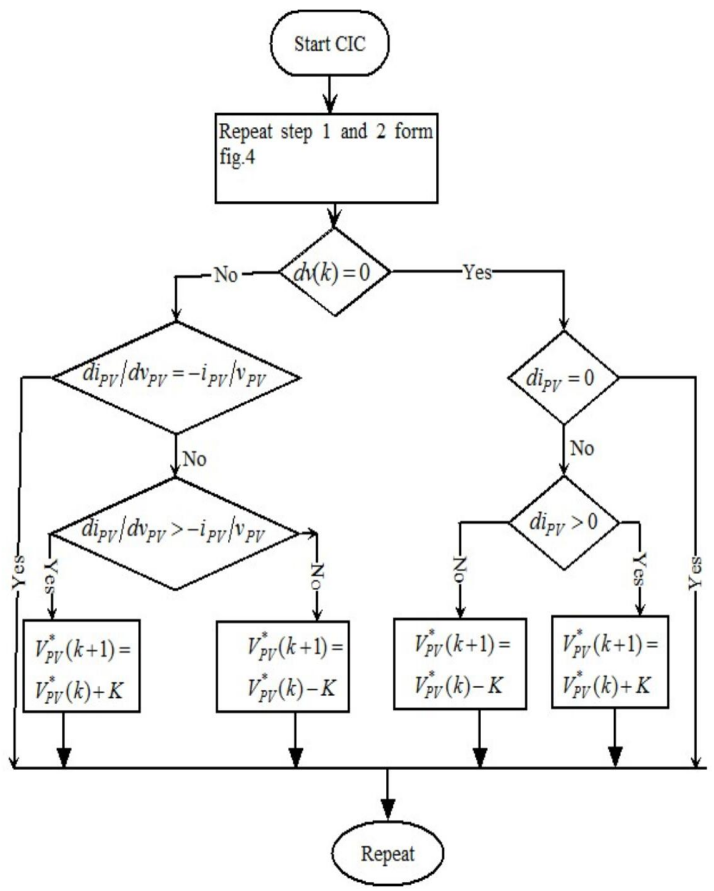

(a)

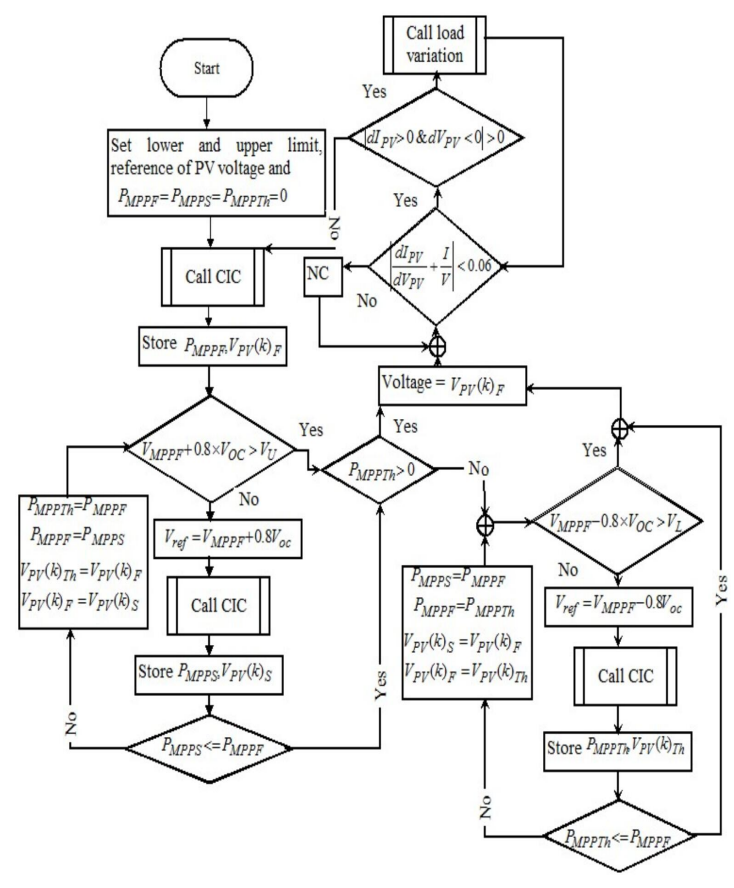

(b)

Figure 5. Flow Chart; (a) Conventional incremental conductance (CIC) algorithm, (b) Modified incremental conductance (MIC) algorithm

\section{FRACTIONAL METHOD}

\subsection{Fractional open circuit voltage}

Different literature suggests that on the PV curve, MP comes in the range of 0.71 to 0.8 times of its open circuit voltage $(\mathrm{OCV})[3,51]$. So a mathematical equation showing relation between the voltages at which maximum power occurs and open circuit voltage is described by following relation-

$$
V_{P V(M P P)}=k_{1} V_{o c} ; \quad 0<k_{1}<1
$$

Fraction open circuit voltage (FOCV) method offers number of advantages as compare with IC and P\&O: (1) It requires only one parameter to measure (voltage); (2) It requires less number of computations; (3) It does not have steady state oscillation like $\mathrm{P} \& \mathrm{O}$ and steady state error like (IC).In order to obtain the power at MPP using above equation, the value of OCV must be measured for different values of solar irradiance and temperature. This measurement can be obtained by either shutting off of $\mathrm{dc} / \mathrm{dc}$ converter or $\mathrm{dc} / \mathrm{ac}$ converter. This intermittent shutdown of PV system for the measurement of open circuit voltage causes significant amount of power loss [52]. This issue can be resolved by using spare PV panel of same rating which is again not economical. A solution to avoid intermittent shut down is to use semi-pilot cell based FOCV [53, 54]. A further improvement in FOCV is done in [49], in which IC as well as FOCV is implemented simultaneously but comparison part is missing. A comparative analysis of FOCV method with different algorithm is given in [55-58].

\subsection{Fractional short circuit current}

Just like FOCV, Fractional short circuit current (FSCC) is simple. Different literatures $[9,59]$ suggest that the value of MP lies in the range of $78 \%$ to $92 \%$ of short circuit current (SCC). So the current at which maximum power occurs can be written in terms of linear equations:

$$
i_{P V(M P P)}=k_{2} I_{s c} ; \quad 0<k_{2}<1
$$


As in case of FOCV, it also requires only one parameter to measure but measuring of SCC is very complex as compared to OCV while PV system is in operation. The modeling and design of grid connected FSCC based MPPT and its validity using MATLAB simulink is done in [60, 61]. To reduce the limitations of $\mathrm{P} \& \mathrm{O}$, a FSCC along with P\&O is used [62-64] to track MPP under normal condition and GMPP under variation of climatic conditions. A further comparative analysis is done in $[65,66]$.

\section{ALGORITHM COMPARISION}

In this research paper a compressive study of duty cycle based algorithm to get the MPP on the most accepted MPPT both under uniform and varying environmental conditions is investigated. Tracking speed, oscillation around MPP, steady state error, energy efficient system, design complexity, ability to track global MPP and ability to track true MPP features are considered while designing an industrially accepted MPPT. The $\mathrm{P} \& \mathrm{O}$ algorithm is the simplest and easier to implement. The complexity in the $\mathrm{P} \& \mathrm{O}$ is less than INC but at the same time the dynamic performance of INC both under uniform and non-uniform condition of solar irradiance is better than that of P\&O. So in terms of simplicity in design and implementation $\mathrm{P} \& \mathrm{O}$ is better choice than INC but in terms of dynamic performance INC is a better choice than P\&O. Both these techniques are facing to track GMMP during varying environmental conditions. The dynamic performance of FM is fastest. The main issue to apply fractional technique is the complication of measuring short circuit current for FSCC and open circuit voltage for FOCV while the PV system is in the state of operating condition. Remarkable supervision has to be taken care to select pilot cell for open circuit voltage measurement such that it has the same feature as the PV array and an additional switch is used to measure short circuit current. Periodical sweep action is needed in case of varying environmental condition of operation. The fractional methods are not able to track the true MPP, so there is always waste of power and less efficient. A performance comparison under different operation is given in table 1 .

Table 1. The performance comparisions

\begin{tabular}{lccccc}
\hline Techniques/Parameters & CP\&O [19]-[24] & MP\&O [22, 25, 26] & CIC [27]-[40] & MIC[41]-[50] & FM[51]-[64] \\
\hline Tracking speed & $\mathrm{M}$ & $\mathrm{MH}$ & $\mathrm{M}$ & $\mathrm{H}$ & $\mathrm{VH}$ \\
Oscillations & $\mathrm{VH}$ & $\mathrm{M}$ & $\mathrm{M}$ & $\mathrm{L}$ & $\mathrm{L}$ \\
Steady state Error & $\mathrm{H}$ & $\mathrm{M}$ & $\mathrm{H}$ & $\mathrm{L}$ & $\mathrm{VH}$ \\
Energy efficient & $\mathrm{M}$ & $\mathrm{VH}$ & $\mathrm{H}$ & $\mathrm{VH}$ & $\mathrm{L}$ \\
Complexity & $\mathrm{M}$ & $\mathrm{H}$ & $\mathrm{M}$ & $\mathrm{H}$ & $\mathrm{L}$ \\
Global MPPT ability & $\mathrm{VL}$ & $\mathrm{VH}$ & $\mathrm{VL}$ & $\mathrm{VH}$ & $\mathrm{L}$ \\
Approaching true MPP & $\mathrm{No}$ & $\mathrm{Yes}$ & $\mathrm{No}$ & $\mathrm{Yes}$ & No \\
\hline
\end{tabular}

Where the notation are: $\mathrm{VH}=$ Very high, $\mathrm{M}=$ Medium, $\mathrm{MH}=$ Medium high, $\mathrm{H}=$ High, $\mathrm{L}=\mathrm{Low}$, VL=Very low.

\section{CONCLUSION}

In the current scenario P\&O and IC are widely accepted at industrial level. On the basis of above review, it can be concluded that the overall response of SPV tracking system depends on perturbation step size and climatic conditions. If there is less step size, the response of MPPT is slow and if there is large step size, the response of MPPT will be fast but at the same time there is oscillation around the MPP. Solar intensity, solar PV temperature and partial shading on solar panel are also changing with time. Hence MPP is shifting with time, so there is a requirement to develop an MPPT algorithm which can identify MPPT zone and has large step size before MPPT zone and small step size within MPPT zone i.e. 71 to $80 \%$ of open circuit voltage and 78 to $90 \%$ of short circuit current. It should also have ability to track global MPP during fast changing climatic conditions.

\section{REFERENCES}

[1] World's largest renewable energy expansion Programme, https://mnre.gov.in, March 2018.

[2] Ministry and E. A. G. of I. Affairs, "11 March 2018 New Delhi, Government of India International Solar Alliance," pp. 11-14, March 2018.

[3] D. V. N. Ananth, "Performance evaluation of solar photovoltaic system using maximum power tracking algorithm with battery backup," Pes T\&D, pp. 1-8, 2012. 
[4] A. K. Gupta and R. Saxena, "Review on widely-used MPPT techniques for PV applications," 1st Int. Conf. Innov. Challenges Cyber Secur. ICICCS-2016, pp. 270-273, 2016.

[5] A. Nawabjan, F. Iqbal, A. S. Abdullah, "A Front Surface Optimization Study for Photovoltaic Application," TELKOMNIKA, Vol.16, No.4, August 2018, pp. 13831387.

[6] L. Jyi-tsong, C. Lai, C. Lee, Y. Hu, K. Ho, and S. W. Haga, "A High-Efficiency HIT Solar Cell With Pillar Texturing," IEEE J. Photovoltaics, vol. Early acce, no. 2156-3381 (C) 2018 IEEE, pp. 1-7, 2018.

[7] N. Mohamed, A. Alrahim, N. Z. Yahaya, and B. Singh, "Single and Two Diode Model of PV Modules: A Comparison," IEEE Int. Conf. Control Syst. Comput. Eng. ICCSCE 2013, pp. 210-214, 2013.

[8] M. Taciuc, "PV cells I-V characteristic. Explicit equation with three parameters and its simplified forms," IEEE 10th Int. Symp. Adv. Top. Electr. Eng., pp. 709-714, 2017.

[9] S. Kouro, B. Wu, H. Abu-rub, and F. Blaabjerg, "Photovoltaic Energy Conversion Systems," Power Electron. Renew. Energy Syst. Transp. Ind. Appl., pp. 160-198, 2014.

[10] G. Spagnuolo, E. Franco, J. D. Bastidas-Rodriguez, C. A. Ramos-Paja, and G. Petrone, "Maximum power point tracking architectures for photovoltaic systems in mismatching conditions: a review," IET Power Electron., vol. 7, no. 6, pp. 1396-1413, 2014.

[11] G. M. Masters Renewable and Efficient Electric Power Systems, Stanford University, Wiley, 2004.

[12] R. S. and R. J. W. Steven A. Ringel, Timothy J. Anderson, Martin A Green, ”Photovoltaic devices," Guid. to State-of-the-Art Electron Devices, First Ed., pp. 213-223,Sept., 2014.

[13] C. S. Solanki, "Solar Photovoltaics," Fundam. Technol. Appl. Ed., PHI, pp. 391-417, 2015.

[14] A. Darwish, A. M. Massoud, D. Holliday, S. Ahmed, and B. W. Williams, "Single-Stage Three-Phase Differential-Mode Buck-Boost Inverters with Continuous Input Current for PV Applications," IEEE Trans. Power Electron., vol. 31, no. 12, pp. 8218-8236, 2016.

[15] M. K. M. Jakeer Hussain, et al., "AdaptiveMaximum Power Point Tracking Control Algorithm forWind Energy Conversion Systems," IEEE Trans. Energy Convers., vol. 31, no. 2, pp. 4003-4007, 2016.

[16] S. W. Hong, S. H. Park, T. H. Kong, and G. H. Cho, "Inverting Buck-Boost DC-DC Converter forMobile AMOLED Display Using Real-Time Self-Tuned Minimum Power-Loss Tracking (MPLT) Scheme With Lossless Soft-Switching for Discontinuous Conduction Mode," IEEE J. Solid-State Circuits, vol. 50, no. 10, pp. 2380-2393, 2015.

[17] G. Petrone. Control of the Power Conversion Chain, Photovolt. Sources Model., JohnWiley \& Sons Ltd., pp. 165-184, 2017.

[18] V. K. Viswambaran, "Modelling and Simulation of Maximum Power point Tracking Algorithms \& Review of MPPT Techniques for PV Applications," IEEE, pp. 4-7,2016.

[19] H. Zhu, D. Zhang, Q. Liu, and Z. Zhou, "Three-Port DC/DC Converter withAll Ports Current Ripple Cancellation Using Integrated Magnetic Technique," IEEE Trans. Power Electron., vol. 31, no. 3, pp. 2174-2186, 2016.

[20] C. S. Solanki Solar Photovoltaics: Fundamentals, Technologies and Applications. PHI 2015.

[21] M. Dini, A. Romani, M. Filippi, and M. Tartagni, "A Nanocurrent Power Management IC for Low-Voltage Energy Harvesting Sources,” IEEE Trans. Power Electron., pp. 4292-4304, 2016.

[22] J. Ahmed, S. Member, and Z. Salam, "A Modified P \& O Maximum Power Point Tracking Method With Reduced Steady-State Oscillation and Improved Tracking Efficiency," IEEE Trans. Sustain. Energy, vol. 7, no. 4, pp. 1506-1515, 2016.

[23] Mohd Asri Jusoh, Mohammad Faridun Naim Tajuddin, Shahrin Md Ayob, Mohd Azrik Roslan, "Maximum Power Point Tracking Charge Controller for Standalone PV System," TELKOMNIKA, vol. 16, no. 4, pp. 1413-1426, 2018.

[24] G. G. Raja Sekhar, Basavaraja Banakar, "Solar PV fed non-isolated DC-DC converter for BLDC motor drive with speed control," Indonesian J Elec Eng \& Comp Sci, vol. 13, no. 1, pp. 313-323, January 2019.

[25] C. Hua, D. Ph, and Y. Chen, "Modified Perturb and Observe MPPT with Zero Oscillation in Steady-State for PV Systems Under Partial Shaded Conditions," IEEE, pp. 5-9,2017.

[26] R. Alik, A. Jusoh, and N. A. Shukri, "An improved perturb and observe checking algorithm MPPT for photovoltaic system under partial shading condition," IEEE Conf. Energy Conversion, CENCON 2015, pp. 398-402, 2015.

[27] S. U. Ramani, S. Kumar, K. Ieee, and B. Arundhati, "Comparitive Study of P\&O and Incremental Conductance method for PV System," International Conference on circuits Power and Computing Technologies [ICCPCT] Comparitive, 2017. 
[28] D. Sera, L. Mathe, T. Kerekes, S. V. Spataru, and R. Teodorescu, "On the perturb-and-observe and incremental conductance mppt methods for PV systems," IEEE J. Photovoltaics, vol. 3, no. 3, pp. 1070-1078, 2013.

[29] M. A. Elgendy, D. J. Atkinson, and B. Zahawi, "Experimental investigation of the incremental conductance maximum power point tracking algorithm at high perturbation rates," IET Renew. Power Gener., vol. 10, no. 2, pp. 133-139, 2016.

[30] G. C. Hsieh, H. I. Hsieh, C. Y. Tsai, and C. H. Wang, "Photovoltaic power-increment-aided incrementalconductance MPPT with two-phased tracking," IEEE Trans. Power Electron., vol. 28, no. 6, pp. 2895-2911, 2013.

[31] G. J. Kish, J. J. Lee, and P. W. Lehn, "Modelling and control of photovoltaic panels utilising the incremental conductance method for maximum power point tracking," IET Renew. Power Gener., vol. 6, no. 4, p. 259, 2012.

[32] S. B. Kjr, et al., "Evaluation of the hill climbing and the incremental conductance maximum power point trackers for photovoltaic power systems," IEEE Trans. Energy Convers., vol. 27, no. 4, pp. 922-929, 2012.

[33] H. S. Moreira, M. Vinicios, L. S. De Araujo, T. Perpetuo, and M. G. Villalva, ”An Experimental Comparative Study of Perturb and Observe and Incremental Conductance Mppt Techniques for Two-Stage Photovoltaic Inverter," 978-1-5090-6248-5/17/ IEEE, pp. 1-6, 2017.

[34] A. Safari and S. Mekhile, "Simulation and hardware implementation of incremental conductance MPPT with direct control method using cuk converter," IEEE Trans. Ind. Electron., vol. 58, no. 4, pp. 1154-1161, 2011.

[35] Y. K. F. Liu, S. Duan, Fei Liu, B. Liu, ”A Variable Step Size INCMPPT Method for PV Systems," IEEE Trans. Ind. Electron., vol. 55, no. 7, pp. 2622-2628, 2008.

[36] M. R. Chavoshian, A. Rouholamini, H. R. Naji, R. Fadaeinedjad, and R. Faraji, "FPGA-based real time incremental conductance maximum power point tracking controller for photovoltaic systems," IET Power Electron.,vol. 7, no. 5, pp. 1294-1304, 2014.

[37] N. Kumar, I. Hussain, B. Singh, and B. K. Panigrahi, ”A Self-Adaptive Incremental Conductance Algorithm for Swift and Ripple-Free Maximum Power Harvesting from PV Array," IEEE Trans. Ind. Informatics, vol. 14, no. 5, pp. 2031-2041, 2018.

[38] Q. Mei, M. Shan, L. Liu, and J. M. Guerrero, ”A novel improved variable step-size incremental-resistance MPPT method for PV systems," IEEE Trans. Ind. Electron.,vol. 58, no. 6, pp. 2427-2434, 2011.

[39] D. Q. G. Xdo et al., "Modified incremental conductance MPPT with Direct control and Dual Scaled Adaptive Step-size," Power Energy Dedic. Adv. Cent., pp. 1-8, 2017.

[40] B. W. Williams, A. A. Helal, M. A. Elsaharty, A. K. Abdelsalam, and N. E. Zakzouk, 'Improved performance low-cost incremental conductance PV MPPT technique," IET Renew. Power Gener., vol. 10, no. 4, pp. 561-574, 2016.

[41] K. S. Tey and S. Mekhilef, "Modified incremental conductance algorithm for photovoltaic system under partial shading conditions and load variation," IEEE Trans. Ind. Electron., vol. 61, no. 10, pp. 5384-5392, 2014.

[42] B. Veerasamy, A. R. Thelkar, G. Ramu, and T. Takeshita, "Efficient MPPT control for fast irradiation changes and partial shading conditions on PV systems," EEE Int. Conf. Renew. Energy Res. Appl. ICRERA 2016, vol. 5, pp. 358-363, 2016.

[43] W. Deng and G. A. J. Amaratunga, "Limits of Incremental Conductance for determining the Maximum Power Point under rapidly changing irradiance and an alternative technique based on fast scanning," IEEE 40th Photovolt. Spec. Conf. PVSC 2014, pp. 3690-3694, 2014.

[44] V. Andrean and K. L. Lian, "A new MPPT method for partially shaded PV system by combining modified INC and simulated annealing algorithm," Int. Conf. High Volt. Eng. Power Syst. ICHVEPS 2017 Proceeding,pp. 388-393, 2017.

[45] M. Unlu, S. Camur, and B. Arifoglu, "A new maximum power point tracking method for PV systems under partially shaded conditions," Int. Conf. Power Eng. Energy Electr. Drives, pp. 1346-1351, May, 2013.

[46] A. Thangavelu, S. Vairakannu, and D. Parvathyshankar, "Linear open circuit voltage-variable step-sizeincremental conductance strategy-based hybrid MPPT controller for remote power applications," IET Power Electron., vol. 10, no. 11, pp. 1363-1376, 2017.

[47] L. L. Jiang, D. R. Nayanasiri, D. L. Maskell, and D. M. Vilathgamuwa, ”A simple and efficient hybrid 
maximum power point tracking method for PV systems under partially shaded condition," IEEE Ind. Electron. Soc., pp. 1513-1518, 2013.

[48] M. Abdulkadir and A. H. M. Yatim, "Hybrid maximum power point tracking technique based on PSO and incremental conductance," IEEE Conf. Energy Convers., pp. 271-276, 2014.

[49] Mohamed Tahar Makhloufi, Yassine Abdessemed, Mohamed Salah Khireddine, "A Feed forward Neural Network MPPT Control Strategy Applied to a Modified Cuk Converter,' IJECE, Vol. 6, No. 4, pp. 14211433, August 2016.

[50] Fransisco Danang Wijaya, Kukuh Daud Pribadi, Sarjiya, "Maximum Power Point Tracking using Particle Swarm Optimization Algorithm for Hybrid Wind-Tidal Harvesting System on the South Coast of Java," IJECE, Vol. 7, No. 2, pp. 659 666pp, April 2017.

[51] O. Lopez-Lapena and M. T. Penella, "Low-power FOCV MPPT controller with automatic adjustment of the sample hold," Electron. Lett., vol. 48, no. 20, p. 1301, 2012.

[52] J. Ahmad, "A fractional open circuit voltage based maximum power point tracker for photovoltaic arrays," Softw. Technol. Eng. (ICSTE), 2010 2nd Int. Conf., vol. 1, pp. 247-250, 2010.

[53] D. Baimel, R. Shkoury, L. Elbaz, and S. Tapuchi, "Novel Optimized Method for Maximum Power Point Tracking in PV Systems Using Fractional Open Circuit Voltage Technique," nt. Symp. Power Electron. Electr. Drives, Autom. Motion, vol. 2, pp. 889-894, 2016.

[54] A. Ramasamy and N. Suthanthira Vanitha, "Maximum power tracking for PV generating system using novel optimized fractional order open circuit voltage- FOINC method," Int. Conf. Comput. Commun. Informatics, pp. 1-6, 2014.

[55] S. Harish, S. S. S, V. Burugula, G. M. J, and P. Raja, ”Design and Performance enhancement of small scale Solar PV fed PMDC motor based water pumping system using PI Controlled FOCV method," Int. Conf. Technol. Adv. Power Energy, pp. 1-6, 2017.

[56] L. El Mentaly, A. Amghar, and H. Sahsah, "Comparison between HC, FOCV and TG MPPT algorithms for PV solar systems using buck converter," Int. Conf. Wirel. Technol. Embed. Intell. Syst. WITS, pp. 1-5, 2017.

[57] M. M. Shebani, T. Iqbal, and J. E. Quaicoe, "Comparing bisection numerical algorithm with fractional short circuit current and open circuit voltage methods for MPPT photovoltaic systems," IEEE Electr. Power Energy Conf. EPEC 2016, pp. 1-5, 2016.

[58] S. Uprety and H. Lee, "A 93\%-Power-Efficiency Photovoltaic Energy Harvester with Irradiance-Aware Auto-Reconfigurable MPPT Scheme Achieving >95\% MPPT Efficiency," IEEE Int. Solid-State Circuits Conf., pp. 378-380, 2017.

[59] M. A. Husain, A. Tariq, S. Hameed, M. S. Bin Arif, and A. Jain, ”Comparative assessment of maximum power point tracking procedures for photovoltaic systems," Green Energy Environ., vol. 2, no. 1, pp. 5-17, 2017.

[60] A. Cheritiuqtrca, "Modeling and Design of PV grid connected system using a modified Fractional Short circuit current MPPT," IEEE, pp. 1-6, 2014.

[61] B. Büyükgüzel and M. Aksoy, "A current-based simple analog MPPT circuit for PV systems," Turkish J. Electr. Eng. Comput. Sci., vol. 24, no. 5, pp. 3621-3637, 2016.

[62] S. K. Kollimalla and M. K. Mishra, "A new adaptive P\&O MPPT algorithm based on FSCC method for photovoltaic system," Proc. IEEE Int. Conf. Circuit, Power Comput. Technol. ICCPCT 2013, pp. 406-411, 2013.

[63] S. K. Kollimalla and M. K. Mishra, ”A novel adaptive p\&o mppt algorithm considering sudden changes in the irradiance," IEEE Trans. Energy Convers., vol. 29, no. 3, pp. 602-610, 2014.

[64] H. A. Sher, A. F. Murtaza, A. Noman, K. E. Addoweesh, K. Al-Haddad, and M. Chiaberge, "A New Sensorless Hybrid MPPT Algorithm Based on Fractional Short-Circuit Current Measurement and P\&O MPPT,” IEEE Trans. Sustain. Energy, vol. 6, no. 4, pp. 1426-1434, 2015.

[65] R. Faranda, S. Leva, and V. Maugeri,"MPPT techniques for PV systems: Energetic and cost comparison," IEEE Power Energy Soc. 2008 Gen. Meet. Convers. Deliv. Electr. Energy 21st Century, PES, pp. 1-6, Feb 2007.

[66] Saravana Selvan, Pratap Nair, Umayal,"A Review on Photo Voltaic MPPT Algorithms," IJECE, Vol. 6, No. 2,pp. 567582 April 2016. 